\title{
MOTYWOWANIE PRACOWNIKÓW W SPÓŁKACH HODOWLANYCH AGENCJI NIERUCHOMOŚCI ROLNYCH
}

\author{
Stanisław Bagieński, Anna Grontkowska \\ Katedra Ekonomiki i Organizacji Przedsiębiorstw \\ Szkoły Głównej Gospodarstwa Wiejskiego w Warszawie \\ Kierownik Katedry: prof. dr hab. Henryk Runowski
}

\begin{abstract}
Słowa kluczowe: motywacja, oczekiwania, umiejętności, pracownik, spółka Key words: motivation, expectations, motive, skills, employee, company

S y n o p s i s. W artykule przedstawiono ocenę motywowania pracowników wykonawczych w spółkach hodowlanych należących do Agencji Nieruchomości Rolnych. W ocenie tej skupiono się na określeniu stopnia zaspokojenia oczekiwań pracowników, rozpoznaniu hierarchii ważności podstawowych motywów pracy oraz ocenie umiejętności kadry kierowniczej dotyczących motywowania pracowników. Z przeprowadzonych badań wynika, że gros oczekiwań pracowników nie było w pełni zaspokajanych. W największym stopniu dotyczyło to oczekiwań związanych z podwyżką wynagrodzeń oraz awansem. Najważniejszymi motywami wykonywania pracy okazały się wysokość wynagrodzenia oraz pewność posiadania pracy. Umiejętności kadry kierowniczej dotyczące motywowania pracowników były na średnim poziomie. W motywowaniu pracowników kadra kierownicza zbyt mało wagi przywiązywała do indywidualnego rozwoju zawodowego poszczególnych pracowników.
\end{abstract}

\section{WSTEPP}

Zarządzanie często definiuje się jako oddziaływanie sprawcze, dzięki któremu ludzie wykonują pożądane rzeczy. Menedżer z założenia nie może wykonywać wszystkiego samodzielnie, musi więc polegać na innych. Działania ludzkie w organizacji oraz ich dążenia do postępu, lepszej pracy są zdeterminowane ich motywacją. Jest to proces wyboru, jakiego dokonują ludzie między różnymi zachowaniami i formami aktywności w celu zaspokojenia pożądanych potrzeb i aspiracji, osiągając jednocześnie określony cel.

Motywowanie w przedsiębiorstwie to zespót oddziaływań, ukierunkowanych na spowodowanie osiagnięcia zamierzonych celów i efektów oraz oczekiwanych postaw i zachowań $l u d z i$ [Oleksyn 2001, s. 142]. Inaczej ujmując motywowanie to proces kierowniczy, który polega na wpływaniu na zachowania innych ludzi. Sukces na tym polu zależy od tego, jak menedżer realizuje (w jakim stylu) proces motywacyjny, czy zna jego mechanizm, jakie zna, jakie opanował i używa środki i narzędzia motywacyjne oraz czy uwzględnia uwarunkowania sytuacyjne.

Skuteczne kierowanie zespołem ludzi (np. załoga przedsiębiorstwa, brygada robotników) wiąże się z poznaniem ludzi, którymi się kieruje, zrozumieniem ich motywów, 
a następnie z ich wykorzystaniem oraz stworzeniem dodatkowych czynników motywujących do bardziej wydajnej i efektywniejszej pracy.

Należy pokreślić, iż każdy człowiek odczuwa określone, indywidualne potrzeby, a ich charakter i nasilenie zależą od czynników kulturowych, psychologicznych, społecznych i ekonomicznych. Jak stwierdził Zdzisław Jasiński cele $i$ oczekiwania pracowników sa funkcja ich cech osobowościowych, ich umiejętności oraz systemów wartości. Wiek, płeć, poziom i rodzaj wykształcenia, doświadczenie zawodowe pracowników, zajmowana pozycja w środowisku pracy, jak również wzorce kulturowe określają ich dążenia [Jasiński 2001, s. 16]. W obliczu tego każdy menedżer powinien wykształcić w sobie zdolność wzbudzania pozytywnej motywacji. Motywacja ta jest wewnętrznym procesem, który wyznacza kierunek działania kończący się osiągnięciem określonego celu (podwyżka, nagroda, awans, bezpieczeństwo zatrudnienia, przynależność do określonej grupy itp.).

Szeroko pojęty obszar motywowania pracowników obejmuje [Patora 2002, s. 23]:

- aspekty kierowania pracownikami,

- wynagrodzenie materialne pracowników,

- wynagrodzenie niematerialne pracowników,

- ocenianie pracowników.

System motywacyjny powinien być powiązany z celami przedsiębiorstwa i wspierać ich realizację. Szczegółowo zatem ujmując można stwierdzić, że na system motywacyjny składają się następujące elementy:

- styl zarządzania (kierowania),

- sposób ustalania celów i planowania działań,

- monitorowanie wyników i ustalanie miar realizacji celów,

- zarządzanie wynagrodzeniami i nagrodami,

- indywidualny rozwój pracowników.

Wszystkie te elementy osadzone są głęboko w kulturze organizacyjnej rozumianej jako zespót założeń, systemu wartości i norm społecznych ukierunkowujących sposoby działania jednostek ludzkich tworzacych przedsiębiorstwo [Bagieński 1996, s. 9-10].

Nie istnieje jeden zintegrowany system diagnozowania systemów motywacyjnych. Można wyróżnić jedynie metody i techniki badające elementy systemu. Są to m.in. ekonomiczne i matematyczne metody analizy efektywności wynagrodzeń oraz określone kwestionariusze badawcze służące do oceny poziomu zaspokajania oczekiwań pracowników, diagnozy hierarchii ważności motywów pracy czy diagnozy umiejętności bezpośredniego przełożonego dotyczących motywowania pracowników.

\section{CEL BADAŃ I METODYKA BADAWCZA}

Celem badań była ocena motywowania pracowników w spółkach hodowlanych należących do Agencji Nieruchomości Rolnych (ANR).

Realizując cel badań, przyjęto następujące zadania badawcze:

- rozpoznanie poziomu zaspokojenia podstawowych oczekiwań pracowników;

- ustalenie hierarchii ważności podstawowych motywów pracy;

- określenie umiejętności bezpośredniego przełożonego dotyczących motywowania pracowników. 
Okresem badawczym były lata 2015-2016. Próbę badawczą stanowili pracownicy wykonawczy spółek hodowlanych należących do Agencji Nieruchomości Rolnych zlokalizowanych w woj. wielkopolskim, gdzie funkcjonuje wiele spółek ANR. W każdej ze spółek w badaniu udział wzięło 10 pracowników. Przy doborze respondentów posłużono się następującymi kryteriami:

- wszyscy respondenci byli zatrudnieni w dziale produkcji roślinnej (poza działem hodowli roślin) na stanowiskach pracowników wykonawczych;

- $\quad$ każdy z badanych pracowników miał zawartą umowę o pracę na czas nieokreślony;

- minimalny okres pracy w badanej spółce w dziale produkcji roślinnej wynosił 3 lata;

- badani pracownicy oraz ich bezpośredni przełożony pracowali w tym samym zakładzie pracy.

W poszczególnych badanych spółkach w dziale produkcji roślinnej pracowało od 23 do 30 pracowników. Liczby te nie obejmują pracowników przypisanych do działu hodowli roślin. Łącznie w badanych spółkach w produkcji roślinnej (poza hodowlą roślin) pracowało 241 pracowników wykonawczych. Przyjęte kryteria spełniło 181 osób. Z tej liczby w badaniu wzięło udział 90 pracowników, co stanowiło niemal 50\% ogółu zatrudnionych pracowników wykonawczych w produkcji roślinnej spełniających przyjęte kryteria.

Podstawową techniką zbierania materiału empirycznego był wywiad z użyciem następujących narzędzi badawczych:

1) kwestionariusza Lawlera i Nadlera służącego ocenie poziomu zaspokojenia 11 podstawowych oczekiwań pracowników [Kozioł 2002, s. 76-79]. Pracownicy anonimowo wypełniali przygotowane kwestionariusze odnoszące się do:

- oceny prawdopodobieństwa wystąpienia zdarzenia zaspokajającego określone oczekiwania,

- oceny poziomu zaspokojenia oczekiwań i poziomu ważności poszczególnych oczekiwań.

Poziom zaspokojenia oczekiwań określono, odejmując od punktów określających prawdopodobieństwo wystąpienia zdarzeń zaspokajających określone oczekiwanie punkty określające ważność tego oczekiwania dla pracowników.

2) kwestionariusza Bluma i Russa umożliwiającego zdiagnozowanie hierarchii ważności wybranych motywów pracy [Kozioł 2002, s. 79-81]. Metoda ta opiera się na założeniu, iż istotną rolę w motywowaniu odgrywa przynajmniej pięć czynników. Zalicza się do nich: awansowanie, płace, stałość pracy, podnoszenie umiejętności zawodowych, relacje z przełożonym. Pracownicy dokonywali wyboru przeciwstawianych sobie czynników (motywów) pracy.

3) kwestionariusza Hellera umożliwiającego diagnozę umiejętności motywowania pracowników przez bezpośredniego przełożonego [Heller 2000, s. 66-69]. Składał się on z 32 pytań odnoszących się do zachowań bezpośredniego przełożonego. Pracownicy oceniali konkretne zachowania bezpośredniego przełożonego w skali od 1 do 4, gdzie 1 oznaczało nigdy, a 4 - zawsze.

\section{WYNIKI BADAŃ}

Nawiązując stosunek pracy, obie strony tego stosunku mają względem siebie określone, nieopisane oczekiwania, nazywane kontraktem psychologicznym [Armstrong, 2011, s. 253-260]. Kontrakt psychologiczny z jednej strony powstaje na podstawie zrozumienia, 
jakich zachowań oczekują pracodawcy od pracowników, a z drugiej - jakich zachowań spodziewają się pracownicy po pracodawcach (kadrze menedżerskiej). Kontrakt psychologiczny jest ważny, gdyż wyzwala emocje, które kształtują zachowania podwładnych. Znaczne różnice we wzajemnych oczekiwaniach pracodawcy i pracownika wywołują na ogół zamieszanie, konflikty, niezadowolenie i obniżają morale pracowników. Stopień zaspokojenia podstawowych oczekiwań pracowników może zwiększać lub zmniejszać ich poziom motywacji.

W tabeli 1. przedstawiono poziom zaspokojenia podstawowych oczekiwań pracowników w badanych spółkach hodowlanych. Poziom ten obliczono, odejmując od skali prawdopodobieństwa wystąpienia zdarzeń zaspakajających określone oczekiwanie skalę ważności tego oczekiwania w ocenie pracownika. Jak wynika z liczb przestawionych w tabeli 1., oczekiwania pracownika z tytułu wykonania swojej pracy szczególnie dobre, takie jak: pochwała otrzymana od kierownika, większa swoboda przy wykonywaniu swojej pracy czy większa życzliwość współpracowników, były w dużym stopniu zaspokojone. Różnica między prawdopodobieństwem wystąpienia sytuacji zaspakajających te oczekiwania a subiektywną ważnością tych oczekiwań dla pracownika w przeliczeniu na 1 respondenta nie przekraczała 1 punktu w skali od 1 do 7 . Znacznie gorzej przedstawiało się zaspokojenie takich oczekiwań jak: otrzymanie podwyżki wynagrodzenia lub nagrody pieniężnej (oczekiwanie nr 1) czy możliwość awansu lub otrzymania lepszej pracy (oczekiwanie nr 6). W tych przypadkach różnica wynosiła ponad 2 punkty. Wynika to, jak się wydaje, z tego, że kadra menedżerska nie zawsze może zaspokoić wszystkie oczekiwania pracowników. Poziom wynagrodzeń zależy, z jednej strony, od sytuacji finansowej przedsiębiorstwa i jego potrzeb inwestycyjnych - rozwojowych, z drugiej zaś strony, od tego jak płacą inne przedsiębiorstwa w branży oraz inne przedsiębiorstwa na rynku lokalnym czy regionalnym.

Wynagrodzenie jako najważniejszy i jednocześnie silnie niezaspokojony motywator wskazali studenci studiów niestacjonarnych, którzy byli zatrudnieni w różnych przedsiębiorstwach [Grontkowska 2011]. Jeżeli poziom wynagrodzeń w danym przedsiębiorstwie nie jest mniejszy od poziomu wynagrodzeń w innych przedsiębiorstwach, to nie ma konieczności (przymusu) zwiększania wynagrodzeń. Z kolei awans zależy przede wszystkim od umiejętności i zdolności pracownika oraz sposobu zorganizowania przedsiębiorstwa (struktury organizacyjnej). Sumienność i staranność wykonywania określonych zadań ma mniejsze znaczenie. Również przy płaskich strukturach organizacyjnych przedsiębiorstw możliwości awansu są bardzo ograniczone, często uniemożliwiające wykorzystanie tego bodźca do zwiększenia motywacji pracowników.

Innym dość istotnym zagadnieniem jest skala ważności wybranych motywów, którymi kierują się pracownicy w trakcie podejmowania i wykonywania pracy. Nie wszystkie motywy (bodźce) są dla poszczególnych pracowników tak samo ważne, istotne. Motywy preferowane przez pracowników w ujęciu ogólnozakładowym są informacją na temat posiadanego potencjału oraz kierunków, w których powinno się ten potencjał doskonalić (zaspokajać jego potrzeby). Motywowanie rozmijające się z potrzebami i oczekiwaniami osób motywowanych jest na ogół mało skuteczne.

W tabeli 2. przedstawiono hierarchię ważności wybranych pięciu motywów pracy w badanej zbiorowości przedsiębiorstw. Z liczb przedstawionych w tabeli 2 . wynika, że wśród pracowników badanych spółek hodowlanych najważniejsze były dwa motywy: wysokość otrzymywanego wynagrodzenia (w 3 spółkach największa liczba wskazań) oraz pewność posiadania pracy (w 4 spółkach największa liczba wskazań). W całej zbiorowości liczba wskazań na te dwa motywy była zbliżona - niemal taka sama i wynosiła 


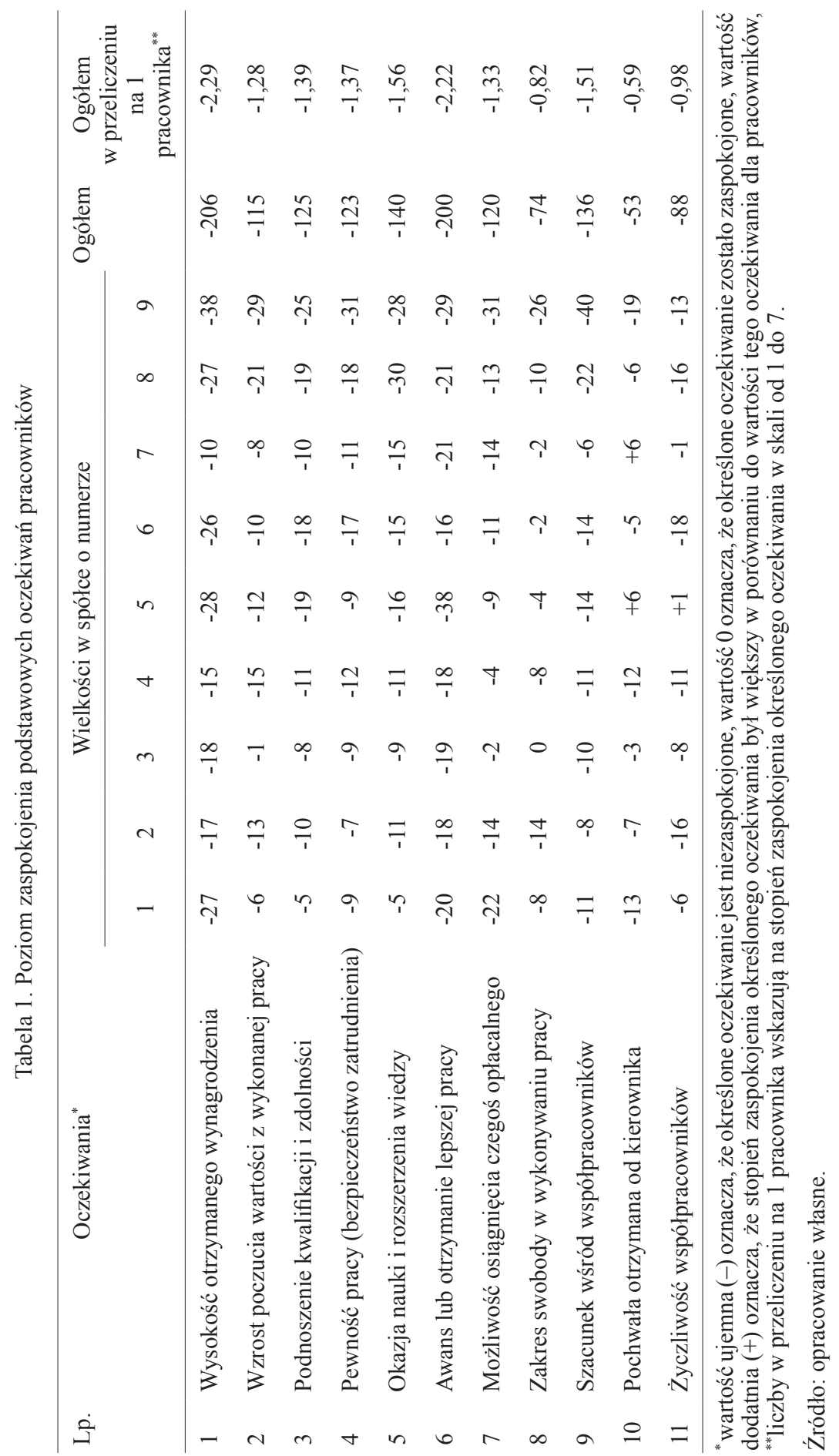


Tabela 2. Hierarchia ważności wybranych motywów pracy

\begin{tabular}{|c|c|c|c|c|c|c|c|c|c|c|c|}
\hline \multirow[t]{2}{*}{ Lp. } & \multirow[t]{2}{*}{ Motywatory } & \multicolumn{9}{|c|}{ Liczba wskazań* w spółce o numerze } & \multirow{2}{*}{$\begin{array}{l}\text { Ogółem } \\
\text { liczba } \\
\text { wskazan }\end{array}$} \\
\hline & & 1 & 2 & 3 & 4 & 5 & 6 & 7 & 8 & 9 & \\
\hline 1. & Poziom wynagrodzenia & 26 & 22 & 18 & 16 & 19 & 35 & 31 & 26 & 31 & 224 \\
\hline 2. & $\begin{array}{l}\text { Pewność posiadania } \\
\text { pracy }\end{array}$ & 31 & 22 & 25 & 30 & 26 & 25 & 23 & 26 & 15 & 223 \\
\hline 3. & $\begin{array}{l}\text { Doskonalenie własnych } \\
\text { umiejętności }\end{array}$ & 17 & 22 & 18 & 25 & 19 & 15 & 19 & 18 & 23 & 176 \\
\hline 4. & $\begin{array}{l}\text { Dobre relacje z } \\
\text { przełożonym }\end{array}$ & 15 & 21 & 24 & 18 & 19 & 14 & 18 & 18 & 9 & 156 \\
\hline 5. & Możliwość awansu & 11 & 13 & 15 & 11 & 17 & 11 & 9 & 12 & 22 & 121 \\
\hline
\end{tabular}

* liczba wskazań odnosi się do wskazania danego motywu jako ważniejszego w porównaniu do innego motywu.

Źródło: opracowanie własne.

odpowiednio 224 oraz 223 wskazania. Wymienione motywy są ściśle ze sobą związane. Na rynku pracy, na którym warunki dyktują pracodawcy, pewność posiadania pracy sprzyja stabilizacji zawodowej oraz gwarantuje stabilizację dochodową na poziomie umożliwiającym zaspokajanie podstawowych potrzeb pracownika i jego rodziny. Taki pracownik czuje się bezpieczniej.

Wśród ogółu badanych pracowników najważniejszym motywem wykonywania pracy było wynagrodzenie i jego wysokość. Jest to, jak się wydaje, w pełni uzasadnione. Większość ludzi musi pracować po to, aby zdobyć fundusze na zakup dóbr niezbędnych do egzystencji. Pieniądze (wynagrodzenie) mogą jednak odgrywać różną rolę i tworzyć nowe możliwości. Pozwalają zaspokajać podstawowe potrzeby, ale też są symbolem osiągnięć społecznych i osobistych wyższego rzędu. Mogą one tracić część swej siły motywacyjnej w miarę, jak osoba wznosi się w hierarchii potrzeb i zdobywa ich coraz więcej. Niemniej potencjał motywacyjny pieniędzy jest duży, ponieważ przynajmniej częściowo są środkiem zaspokajania wielu potrzeb zarówno młodych, jak i starszych ludzi.

$\mathrm{Na}$ trzecim miejscu w hierarchii ważności, spośród przyjętych w badaniu pięciu motywów pracy, znalazł się motyw doskonalenia własnych umiejętności zawodowych. Jest to motyw często niedoceniany przez kadrę kierowniczą, wynikający z braku przemyślanej polityki doskonalenia zawodowego pracowników. Takiemu myśleniu sprzyja także relatywnie niższy poziom wykształcenia większości pracowników wykonawczych i stosunkowo często niska motywacja do pracy zniechęcająca pracodawców (kadrę kierowniczą) do inwestowania w ich rozwój. Również bywa tak, że koszty doszkalania pracowników mogą przekraczać możliwości ich realizacji.

Od pracowników wykonawczych w większości przypadków oczekuje się samodzielności (przy wykonywaniu rutynowych prac), staranności i dobrej jakości, odpowiedzialności za wyniki, uczciwości, lojalności i kultury pracy.

Niezależnie od motywów, którymi kadra kierownicza kieruje się przy kształtowaniu zasobów ludzkich przedsiębiorstwa, pracownicy wykonawczy powinni mieć również możliwość doskonalenia swoich umiejętności zawodowych. W odniesieniu do pracowników 
Tabela 3. Umiejętności przełożonych dotyczące motywowania pracowników

\begin{tabular}{ccccc}
\hline \multirow{2}{*}{$\begin{array}{c}\text { Numer } \\
\text { spółki }\end{array}$} & \multicolumn{3}{c}{$\begin{array}{c}\text { Liczba pracowników wskazujących na umiejętności } \\
\text { przełożonego jako: }\end{array}$} & $\begin{array}{c}\text { Średnia ocena } \\
\text { punktowa }\end{array}$ \\
\cline { 2 - 5 } & niskie (32-63)* & średnie $(64-95)^{*}$ & wysokie (96-128)* \\
\hline 1 & 3 & 5 & 2 & 76,6 \\
2 & - & 7 & 3 & 85,3 \\
3 & - & 10 & - & 82,8 \\
4 & 1 & 5 & 4 & 83,6 \\
5 & 1 & 7 & 2 & 79,4 \\
6 & 2 & 5 & 3 & 84,5 \\
7 & 1 & 7 & 2 & 79,9 \\
8 & 2 & 8 & - & 72,2 \\
9 & - & 10 & - & 73,2 \\
Razem & 10 & 64 & 16 & 79,7 \\
\hline
\end{tabular}

* w nawiasach podano przedziały punktów przyjętych jako kryteria do wyodrębnienia trzech grup umiejętności motywowania

Źródło: opracowanie własne.

wykonawczych zainteresowanych doskonaleniem zawodowym przydatnym i relatywnie mało kosztownym rozwiązaniem, sprzyjającym doskonaleniu zawodowemu może być, jak się wydaje, stopniowe poszerzanie treści pracy. Po opanowaniu jednych prac mogą oni uczyć się następnych. Zwiększa to elastyczność zatrudnienia i przeciwdziała monotonii pracy.

Kolejnym aspektem przeprowadzonych badań było rozpoznanie umiejętności bezpośrednich przełożonych dotyczących motywowania podległych im pracowników. Oceny tej dokonali pracownicy wykonawczy wypełniający kwestionariusz diagnostyczny Hellera, składający się z 32 pytań opisujących zachowania bezpośrednich przełożonych. Zadaniem pracowników było wskazanie, jak często bezpośredni przełożony zachowuje się zgodnie z opisaną sytuacją według skali: nigdy -1 p., rzadko -2 p., często -3 p. i zawsze -4 p. Otrzymane wyniki przedstawiono w tabeli 3.

Jak wynika z danych przedstawionych w tabeli 3., w opinii większości pracowników (około $71 \%$ ogółu respondentów) umiejętności bezpośrednich przełożonych dotyczące motywowania pracowników były na poziomie średnim. Prawie $18 \%$ ogółu pracowników wskazało na umiejętności wysokie. To dobrze świadczy o kadrze menedżerskiej badanych spółek. Pracownicy dostrzegają, że bezpośredni przełożeni starają się im dostarczyć właściwej motywacji. Te umiejętności wynikają zarówno z doświadczenia i intuicji, jak i z predyspozycji osobowościowych oraz wiedzy z zakresu zarządzania, psychologii i socjologii.

Na uznanie zasługuje fakt, że w większości badanych spółek kadra menedżerska, jeżeli jest to konieczne, przekazuje pracownikom pełne i precyzyjne informacje. Analizując podejście pracowników do pracy, wyciąga na ogół właściwe wnioski. W swoich zachowaniach dąży do porozumienia i zachęca innych do tego samego. Organizując pracę, dąży do równowagi pomiędzy ścisłą kontrolą pracowników a dawaniem im swobody działania. W tych kwestiach ogół respondentów (90 pracowników) wskazał odpowiedzi, których średnia ocena oscylowała wokół 3 punktów.

Nie we wszystkich kwestiach dotyczących umiejętności motywowania ocena pracowników była tak pozytywna. W opinii ogółu respondentów kadra menedżerska badanych 
spółek zbyt małą uwagę przywiązywała do tego, by zadania trudne bądź specjalne traktować jako okazję do rozwoju personelu. Przydzielanie poszczególnym pracownikom zadań specjalnych, często wykraczających poza zakres ich obowiązków, może być, jak się wydaje, jednym ze sposobów pomocnych w procesie rozwoju zawodowego podległego personelu. W tym sposobie rozwoju zawodowego pracowników nieodzowne jest wykazywanie przez kadrę kierowniczą zainteresowania postępem prac i udzielanie, jeżeli to konieczne, pracownikom wsparcia. W opinii ogółu respondentów kadra kierownicza nie stara się również uzyskać informacji zwrotnej od pracownika, którego z różnych powodów krytykuje oraz zbyt rzadko dziękuje pracownikom za dobrze wykonana pracę. W tych kwestiach średnia ocena dla całej zbiorowości nie przekraczała 2 punktów. Należy jednak nadmienić, że oczekiwanie pracownika związane z uzyskaniem pochwały od kierownika za szczególnie dobre wykonanie przydzielonej pracy było prawie w pełni zaspokojone (tabela 1.).

Średnia ocena z 32 sytuacji opisujących zachowania menedżerów związane z umiejętnościami motywowania pracowników była relatywnie wysoka i wynosiła prawie 80 punktów. Świadczy to dobrze o kadrze menedżerskiej badanych spółek.

\section{WNIOSKI}

Z przeprowadzonych badań empirycznych wynikają następujące wnioski:

1. Kadra kierownicza badanych spółek hodowlanych nie wszystkie oczekiwania pracowników wykonawczych związane z podjęciem i wykonywaniem pracy mogła w pełni zaspokoić. Dotyczy to zwłaszcza takich oczekiwań, jak podwyżka wynagrodzeń czy awans.

2. Spośród pięciu przyjętych w badaniu motywów wykonywania pracy najważniejszymi dla pracowników były wysokość wynagrodzenia oraz pewność posiadania pracy. W całej badanej zbiorowości liczba wskazań na te dwa motywy była największa i prawie identyczna.

3. Kadra menedżerska badanych spółek hodowlanych zbyt małą wagę przywiązywała do potrzeb pracowników wykonawczych związanych z ich indywidualnym rozwojem zawodowym.

4. Umiejętności bezpośrednich przełożonych (kadry kierowniczej) dotyczące motywowania pracowników były na średnim poziomie. Przeciętna ocena odzwierciedlająca te umiejętności wynosiła 80 punktów - na 128 punktów możliwych do otrzymania. Należy podkreślić, że wśród ogółu respondentów biorących udział w badaniu (90 osób) prawie 18\% pracowników wystawiło noty wskazujące na wysokie umiejętności kadry kierowniczej w tym zakresie.

\section{LITERATURA}

Armstrong Michael, 2011: Zarzadzanie zasobami ludzkimi. Wyd. Wolters Kluwer, Warszawa, s. 253-260.

Bagieński Stanisław, 1996: Kultura organizacyjna kadry kierowniczej a funkcjonowanie rolniczych spółdzielni produkcyjnych. Wyd. SGGW, Warszawa, s. 9-10.

Grontkowska Anna, 2011: Co motywuje studentów studiów niestacjonarnych kierunku ekonomia Szkoły Głównej Gospodarstwa Wiejskiego w pracy zawodowej? „Zeszyty Naukowe SGGW w Warszawie. Ekonomika i Organizacja Gospodarki Żywnościowej”, nr 88, s. 279-289. 
Heller Robert, 2000: Motywowanie pracowników. Wyd. Wiedza i Życie, s. 66-69.

Jasiński Zdzisław (red.) 2001: Motywowanie w przedsiębiorstwie. Agencja Wydawnicza PLACET, Warszawa, s. 16.

Kozioł Leszek, 2002: Motywacja w pracy. Wyd. Naukowe PWN, s. 76-81.

Oleksyn Tadeusz, 2001: Praca i płaca w zarządzaniu. Wyd. Międzynarodowa Szkoła Menedżerów, s. 142.

Patora Roman, 2002: Motywowanie w przedsiębiorstwie jako przykład działalności pedagogicznej. „Przegląd Organizacji”, nr 1, s. 23.

\section{Stanisław Bagieński, Anna Grontkowska}

\section{MOTIVATING EMPLOYEES IN BREEDING COMPANIES OF THE AGRICULTURAL PROPERTY AGENCY}

\section{Summary}

The aim of the paper was to evaluate motivating of the workforce in state owned breeding companies of the Agricultural Property Agency. The evaluation focused on the level of meeting employees'expectations, identification of the hierarchy of motives as well as assessment of managers'skills in the field of motivating employees. The results of the study show that the majority of employees' expectations were not met. It applied particularly to expectations connected with wage increase and promotion. Both level of wage and work stability turned out to be the most important motives. Managerial skills in motivating employees to work were rated as mediocre. Managers attached too little attention to professional development of individual employees.

Adres do korespondencji: Dr hab. Stanisław Bagieński, prof. SGGW, dr inż. Anna Grontkowska

Szkoła Główna Gospodarstwa Wiejskiego w Warszawie Katedra Ekonomiki i Organizacji Przedsiębiorstw 02-787 Warszawa, ul. Nowoursynowska 166 e-mail: stanisław_bagienski@sggw.pl, anna_grontkowska@sggw.pl 